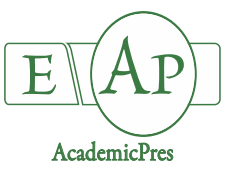

Zhu Y-Q et al. (2021)

Notulae Botanicae Horti Agrobotanici Cluj-Napoca

Volume 49, Issue 2, Article number 12173

DOI: $10.15835 /$ nbha 49212173

Research Article

\title{
Comparison of photosynthetic fluorescence characteristics of several submerged plants in Honghu Lake, China
}

\author{
Yuan-Qin ZHU ${ }^{1}$, Bo-Han JING ${ }^{1}$, Long-Yi YUAN ${ }^{1,2 *}$ \\ ${ }^{1}$ Yangtze University, College of Horticulture and Gardening, Jingzhou, 434025, China; 1207467937@qq.com; yly35@qq.com \\ ${ }^{2}$ Yangtze University, Engineering Research Center of Ecology and Agricultural Use of Wetland, Jingzhou,434025, China; \\ yzq29@sina.com (*corresponding author)
}

\begin{abstract}
Submerged plants are the pioneer species of eutrophic water remediation, and they are important for maintaining the health of aquatic ecosystem, while light is the main limiting factor for the growth of submerged plants. In this study, we measured the maximal quantum yields of photosystem $\mathbb{I}\left(F_{v} / F_{m}\right)$ and rapid light curves (RLCs) of five dominant submerged macrophytes in situ by using pulse-amplitude modulated fluorometer (Diving-PAM). Results revealed that $P$. crispus $\mathrm{L}$. and $M$. verticillatum $\mathrm{L}$. had the highest $F_{v} / F_{m}$ value, all species' $F_{v} / F_{m}$ are less than 0.8 . In addition, the variation trends of $F_{v^{\prime}} / F_{m^{\prime}}$ and $F_{v} / F_{m}$ were same. All species showed statistically significant differences in $\alpha$, while P. crispus $\mathrm{L}$. and $M$. verticillatum $\mathrm{L}$. showed the highest $\alpha$ value in the five species. And the variation trends of $\mathrm{rETR}_{\mathrm{m}}$ and $\mathrm{E}_{\mathrm{k}}$ were basically the same. It indicated that P. crispus L. and M. verticillatum L., both of which had high photosynthetic efficiency, had excellent ability to withstand hard light. Compared five species, P. crispus L. and M. verticillatum L. had resistance capacity to hard light as well as faster photosynthetic rate, and $V$. natans (Lour.) Hara had higher resistance capacity to low light. Thus, when submerged plants are used for water restoration, $V$. natans (Lour.) Hara could be regarded as a pioneer species in eutrophication water restoration. P. crispus $\mathrm{L}$. and $M$. verticillatum $\mathrm{L}$. will have better effects when used in shallow water areas.
\end{abstract}

Keywords: Honghu Lake; submerged macrophytes; rapid light curve; quantum yield

\section{Introduction}

During the past several decades, most lakes around the world have been suffering from eutrophication(Smith and Schindler, 2009; Yang et al., 2017).The causes of lake eutrophication are various: Under the combined interference of natural and man-made factors, a large amount of nutrients are imported into the lake, resulting in an increase in carbon, nitrogen, phosphorus and other source elements in the water body, which leads to an increase in phytoplankton biomass and a decrease in water transparency, gradually transforming it from a nutrient-poor lake to a nutrient-rich lake (Qin et al., 2013; Bal et al., 2017; Liao et al., 2017).Lake eutrophication is the most serious water quality problem in the world, which directly causes the frequent occurrence of toxic algal blooms, the death of fish, the decline of biodiversity, the degradation of lake ecological structure and function and other related ecological problems (David et al., 2008; Wang and Wang, 2009).

Received: 30 Nov 2020. Received in revised form:06 Apr 2021. Accepted: 27 Apr 2021. Published online: 05 May 2021.

From Volume 49, Issue 1, 2021, Notulae Botanicae Horti Agrobotanici Cluj-Napoca journal uses article numbers in place of the traditional method of continuous pagination through the volume. The journal will continue to appear quarterly, as before, with four annual numbers. 
Submerged plants are important structural shapers and functional maintainers of lake ecosystems. Using submerged plants to repair eutrophic lakes has the characteristics of low cost, low carbon and environmental protection, and is a truly sustainable management method (Zhang et al., 2012).However, Light is one of the major factors limiting the growth of submerged macrophytes (Barko and Smart, 1981)and plays a decisive role in the growth and spatial distribution of submerged plants (Bornette and Puijalon, 2011).The decrease of water transparency caused by eutrophication directly leads to the deterioration of underwater light environment, which reduces the photosynthetic capacity of submerged plants, and then leads to the disappearance of a large number of submerged plants (Gudrun and Sara, 2011; Zhao et al., 2018). Our aim is to find a pioneering species with strong photosynthetic capacity in low-light environments with low water transparency, so as to provide a theoretical basis for eutrophication management of shallow lakes.

$V$. natans (Lour.) Hara, $H$. verticillata, $M$. verticillatum L., $P$. crispus $\mathrm{L}$. and $P$. wrightii Morong are dominant species of submerged plant communities in shallow lakes (water depth is around $150 \mathrm{~cm}$ ) in the middle and lower reaches of the Yangtze River with high pollution tolerance and high pollution absorption. In recent years, the studies on these submerged plants mainly focus on the absorption of nitrogen, phosphorus and heavy metals (Yang et al., 2015; Zhang et al., 2015; Xie et al., 2016), mostly by laboratory simulation experiments.

Chlorophyll fluorescence dynamics technology is a rapid, simple, accurate and non-damaging measurement, which is an important means of detecting and analyzing the relationship between plant photosynthesis and the environment (Zhang, 1999; Küster and Altenburger, 2007; Liu et al., 2010). At present, fluorescence technology has been widely used in the physiological and ecological research of terrestrial higher plants, as well as large seagrass and coral, but less applied in the physiological and ecological research of aquatic higher plants in fresh water (Lamote and Dunton, 2006; Belshe et al., 2007; Hallik et al., 2012; Wang et al., 2015; Zhong et al., 2018; Liu et al., 2019). Existing studies on the fluorescence characteristics of higher aquatic plants in fresh water mostly focus on the comparative analysis of ecological factors on aquatic plant stress under experimental control conditions. However, studies on the comparison of photosynthetic fluorescence parameters of aquatic plants in natural habitats have rarely been reported (Hussain et al., 2019). In this study, we measured main leaf fluorescence kinetics parameters and fast light response curve of five kinds of submerged plant by using in-situ detecting method, and compared their PSII main fluorescence parameters characteristics in natural water, aiming at providing a theoretical basis for remediation of lake eutrophication by submerged plants.

\section{Materials and Methods}

\section{Site and conditions}

Honghu Lake $\left(\mathrm{N} 29^{\circ} 42^{\prime} \sim 29^{\circ} 58^{\prime}\right.$, E113 $\left.13^{\circ} \sim 113^{\circ} 29^{\prime}\right)$ is the largest lake in Hubei province, China, lying on the north shore of the Yangtze River middle reaches, which plays a significant role in water supply, flood storage and drainage, pollution self-purification, agricultural and fishery production in the Jianghan Plain of the middle and lower reaches of the Yangtze River (Liu et al., 2004). The vegetation division is part of the arctic plant region and the China-Japan forest plant subregion. From the shore to the center of the lake, there are wet plants (Polygonum hydropiper L. et al.), emergent plants (Zizania latifolia et al.), floating-leaved plants (Trapa natans et al.), submerged plants ( $V$. natans (Lour.) Hara et al.) and other ecological types successively (Li, 1997).

\section{Methods}

Taking the dense growth of submerged plants in Honghu ravine as the sampling area, five common submerged plants: V. natans (Lour.) Hara, $H$. verticillata, $M$. verticillatum L., P. crispus $\mathrm{L}$. and $P$. wrightii Morong (all these submerged plants were identified by Flora of China (Wu, 2007)) were selected as the research 
objects, and their leaf green fluorescence parameters were determined in situ by Diving-PAM. We selected 3 samples from each plant in the lake area with a water depth of $150 \mathrm{~cm}$ randomly, and $1-2$ fully developed healthy leaves were selected for each plant.

$F_{v} / F_{m}$ is PSII maximum photochemical quantum yield, they reflect the PSII intrinsic light energy conversion efficiency, which can be described by the equation:

$F_{v} / F_{m}=\left(F_{m}-F_{o}\right) / F_{m}$.

where $F_{o}$ is the minimal fluorescence (testing light is $0.15 \mu \mathrm{mol} \cdot \mathrm{m}^{-2} \cdot \mathrm{s}^{-1}$ ); $F_{m}$ represents the maximal fluorescence (saturation pulse light is $4000 \mu \mathrm{mol} \cdot \mathrm{m}-2 \cdot \mathrm{s}-1$ ).

PSII photochemical effective quantum yield of photochemical reaction $\left(F_{v}^{\prime} / F_{m}\right)$ can be described by the equation:

$F_{v}{ }^{\prime} / F_{m}{ }^{\prime}=\left(F_{m}{ }^{\prime}-F_{o}\right) / F_{m}{ }^{\prime}$

where $F_{o}{ }^{\prime}$ and $F_{m}{ }^{\prime}$ represent the minimal and the maximal fluorescence under the condition of actinic light adaptation, respectively.

Then, actinic light was turned on at the intensity of $33,104,219,342,515,708,1042$ and $1407 \mu \mathrm{mol} \cdot \mathrm{m}$

${ }^{2} \cdot s^{-1}$, respectively. The fluorescence before turning on the saturation pulse was recorded as $F_{t}$ and the

fluorescence measured after turning on the saturation pulse light was recorded as $F_{m}{ }^{\prime}$, then we got variable fluorescence $(\triangle F): \triangle F=F_{m}^{\prime}-F_{t}$, the effective quantum yield $(\mathrm{Y})$ can be calculated:

$\mathrm{Y}=\left(F_{\mathrm{m}}{ }^{\prime}-F_{\mathrm{t}}\right) / F_{m}{ }^{\prime}=\triangle F / F_{m}{ }^{\prime}$

Relative electron transport rate (rETR) was described by the equation (Ralph et al., 1998):

$\mathrm{rETR}=\mathrm{Y} \times \mathrm{PAR} \times 0.5 \times 0.84$

The least square method was used for the fast light curve fitting, and the equation we used is proposed by Platt (Platt et al., 1980). and Ralph (Ralph and Gademann, 2005). The equation is as follows:

$\mathrm{rETR}=\mathrm{rETR}_{\mathrm{m}}\left(1-\mathrm{e}^{-\alpha . \mathrm{PAR} / \mathrm{EETRm}}\right) \mathrm{e}^{-\beta . \mathrm{PAR} / \mathrm{rETRm}}$

where, $\mathrm{rETR}_{\mathrm{m}}$ is the maximum potential relative electron transfer rate in the absence of light inhibition, $\alpha$ is the initial slope of the rETR-PAR curve, reflecting the ability of plants to use light energy, $\beta$ is the photoinhibition parameter. Thus, the half-saturated light intensity $\left(E_{k}\right)$ is $E_{k}=r E T R_{m} / \alpha$.

\section{Statistical analysis}

Microsoft Excel 2018 and IBM SPSS Statistics 22.0 were used for statistical analysis of all data, all diagrams were drawn by Origin 2018 and one-way ANOVA was used to compare the differences between different data groups.

\section{Results}

\section{Comparison of light parameters of five submerged plants}

$F_{v} / F_{m}$ reflect the PSII intrinsic light energy conversion efficiency. PSII $F_{v} / F_{m}$ of 5 plants were $V$. natans (Lour.) Hara respectively $0.603, H$. verticillata $0.723, M$. verticillatum L. $0.751, P$. crispus $\mathrm{L} .0 .778, P$. wrightii Morong 0.646 (Figure 1). Among them, the difference of $F_{v} / F_{m}$ between $V$. natans (Lour.) Hara and the other four submerged plants reached a significant level $(P<0.05)$, as well as $P$. wrightii Morong, while the $F_{v} / F_{m}$ of $V$. natans (Lour.) Hara was the smallest among the tested plants, followed by $P$. wrightii Morong. There is no significant difference in $F_{v} / F_{m}$ between $H$. verticillata and $P$. crispus L. $(P<0.05)$, and the $P$. crispus $\mathrm{L}$. showed higher $F_{v} / F_{m}$ than $H$. verticillata, simultaneously. No significant differences in $F_{v} / F_{m}$ between $M$. verticillatum L. and $H$. verticillata or $P$. crispus L. were observed.

$F_{v} \cdot F_{m}$ 'reflect open PSII reaction center original light trapping efficiency (Waldhoff et al., 2002).PSII $F_{v}{ }^{\prime} / F_{m}{ }^{\prime}$ of 5 plants were $V$. natans (Lour.) Hara respectively $0.423, H$. verticillata $0.574, M$. verticillatum $\mathrm{L}$. 0.608 , P. crispus L.0.653 and $P$. wrightii Morong 0.493 , respectively (Figure 1 ). Among them, the difference of $F_{v} / F_{m}$ between $V$. natans (Lour.) Hara and other four plants reached a significant level $(P<0.05)$, as well as $P$. 
crispus $\mathrm{L}$. and $P$. wrightii Morong. Moreover, the $F_{v}{ }^{\prime} / F_{m}{ }^{\prime}$ of $P$. crispus $\mathrm{L}$. is the highest, $P$. wrightii Morong is the second, and $V$. natans (Lour.) Hara is the lowest. However, the differences of $F_{v}^{\prime} / F_{m}$ between $H$. verticillata and $M$. verticillatum L. are not significant, and their $F_{v}^{\prime} / F_{m}^{\prime}$ are lower than $P$. crispus L. and higher than $P$. wrightii Morong, significantly.

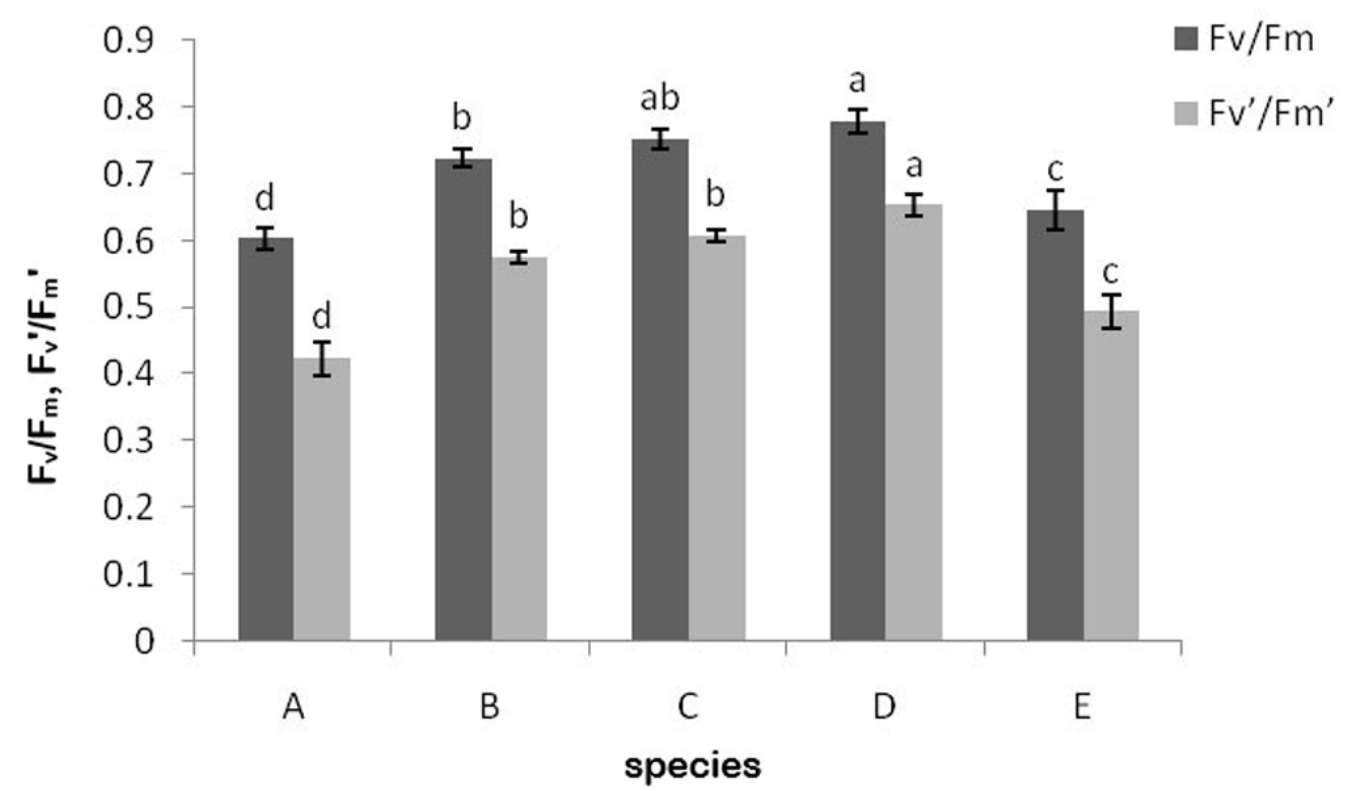

Figure 1. Comparative study on $F_{v} / F_{m}$ and $F_{v}{ }^{\prime} / F_{m}{ }^{\prime}$ of submerged macrophytes

(A means V. natans (Lour.) Hara B means $H$. verticillata (L. f.) Royle C means $M$. verticillatum L. D means $P$. crispus L. E means $P$. wrightii Morong. the same as below. The different normal letters represent significant differences among species at 0.05 level, the same as below.)

\section{Rapid light curve analysis of different submerged plants}

As can be seen from Figure 2, rapid light curves (RLCs) of five common submerged plants show obvious changes, which can be fitted by exponential attenuation equation ( $\mathrm{Li}$ et al., 2008) $\left(\mathrm{R}^{2}>0.998, \mathrm{n}=9\right)$. By analyzing RLCs, a series of parameters reflecting photosynthetic capacity can be obtained.

$\alpha$ is the initial slope of the rETR-PAR curve, reflecting the ability of plants to use light energy. $\alpha$ of five plants were respectively $V$. natans (Lour.) Hara $0.213, H$. verticillata $0.373, M$. verticillatum L. 0.348 , P. crispus L. 0.487 , and $P$. wrightii Morong 0.317 (Figure 3 ), among which, the difference of between $H$. verticillata and $M$. verticillatum $\mathrm{L}$. was not significant, but the difference between $H$. verticillata and other three plants reached a significant level $(P<0.05)$, as well as $M$. verticillatum $\mathrm{L}$. In addition, $P$. crispus $\mathrm{L}$. had the highest $\alpha, H$. verticillata and $M$. verticillatum $\mathrm{L}$. are in the middle level, $P$. wrightii Morong is next, $V$. natans (Lour.) Hara is the lowest.

$\mathrm{rETR}_{\mathrm{m}}$ is the maximum potential relative electron transfer rate of plants under no light inhibition. As shown in Figure 4, the rETR $\mathrm{m}_{\mathrm{m}}$ of the 5 plants were respectively V. natans (Lour.) Hara 12.3, H. verticillata 28.6, M. verticillatum L. 38.4, P. crispus L. 51.7, and P. wrightii Morong 16.5, Among them, the differences in $\mathrm{rETR}_{\mathrm{m}}$ between each submerged plant reached a significant level $(P<0.05)$. This indicates that the maximum potential relative electron transfer rate of the five submerged plants during the period of no light inhibition is $P$. crispus L. $>M$. verticillatum L. $>$ H. verticillata $>$ P. wrightii Morong $>$ and V. natans (Lour.) Hara.

Half-saturated light intensity $\left(E_{k}\right)$ reflects the tolerance of plants to hard light. As shown in Figure 5 , $\mathrm{E}_{\mathrm{k}}$ of the five plants were respectively $V$. natans (Lour.) Hara 57.90, $\mathrm{H}$. verticillata $76.63, M$. verticillatum $\mathrm{L}$. 110.35, P. crispus L. 106.15, and P. wrightii Morong 51.99, among them, the $\mathrm{E}_{\mathrm{k}}$ differences between P. crispus L. and $M$. verticillatum $L$ were not significant, however, they reached a significant level with other 3 plants 
respectively $(P<0.05)$. And these five submerged plants showed high light tolerance, $P$. crispus $\mathrm{L}$. and $M$. verticillatum $\mathrm{L}$. were the strongest, $H$. verticillata is in the middle level, $V$. natans (Lour.) Hara is next, $P$. wrightii Morong is the weakest.

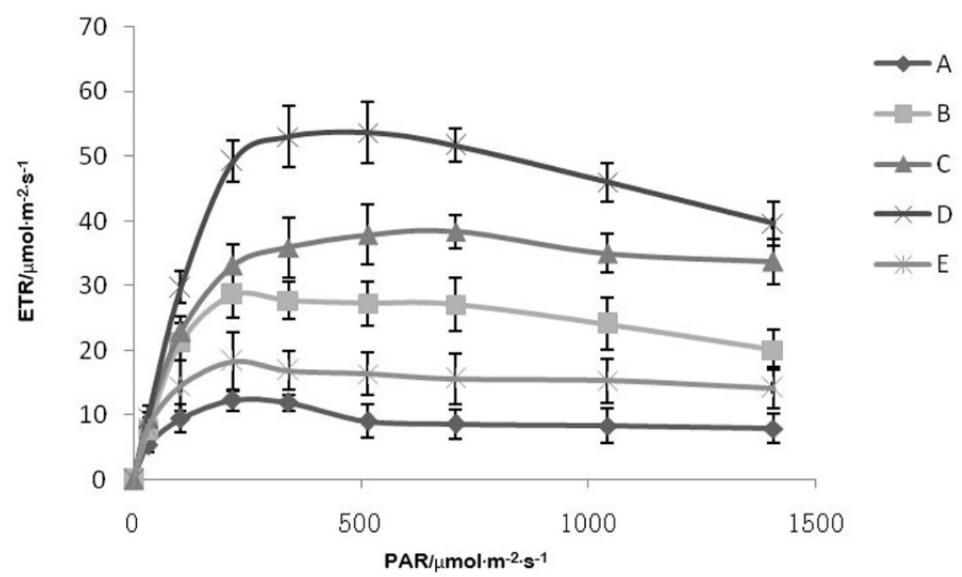

Figure 2. Comparative study on the rapid light curves of five submerged macrophytes

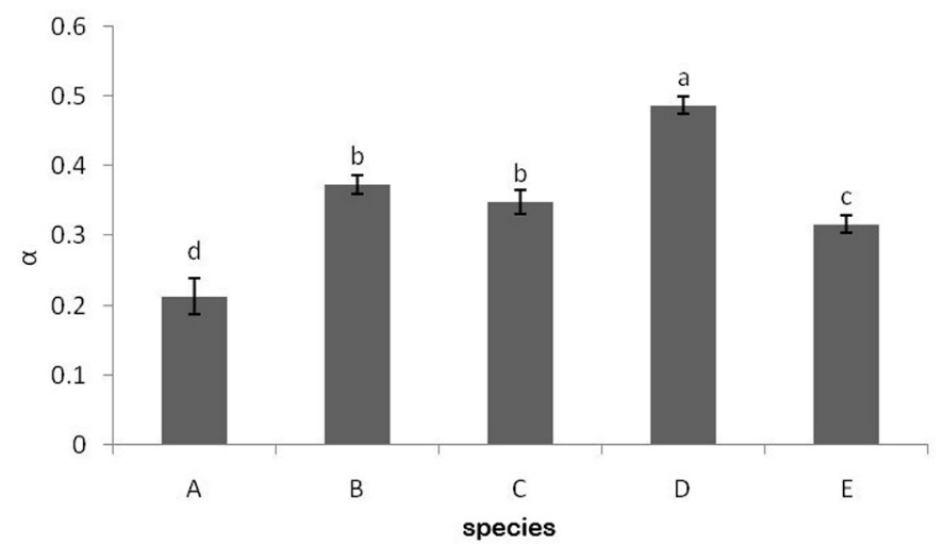

Figure 3. Comparative study on the $\alpha$ of five submerged macrophytes

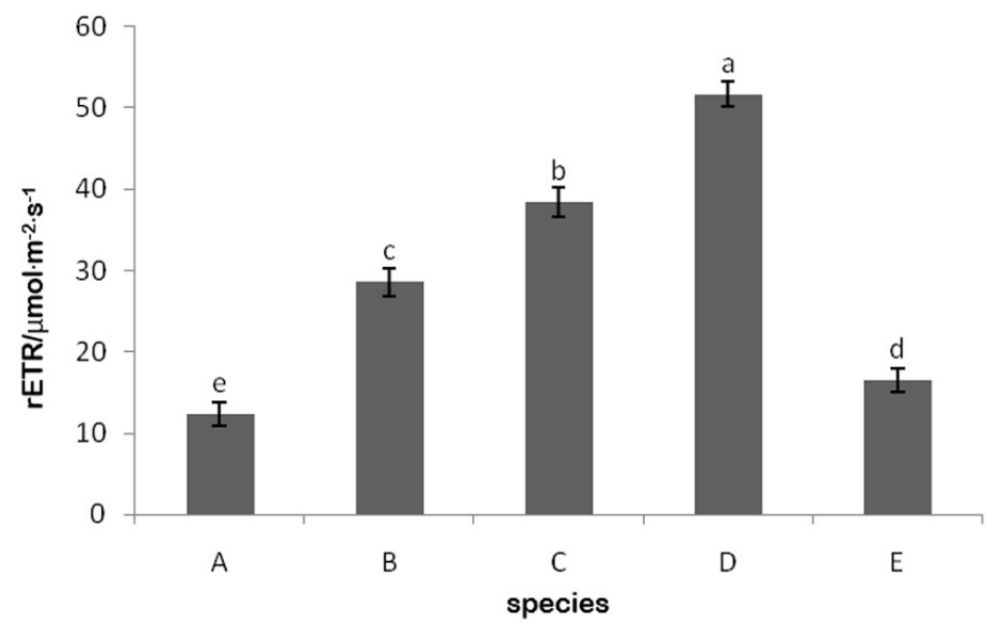

Figure 4. Comparative study on the $\mathrm{rETR}_{\mathrm{m}}$ of five submerged macrophytes 


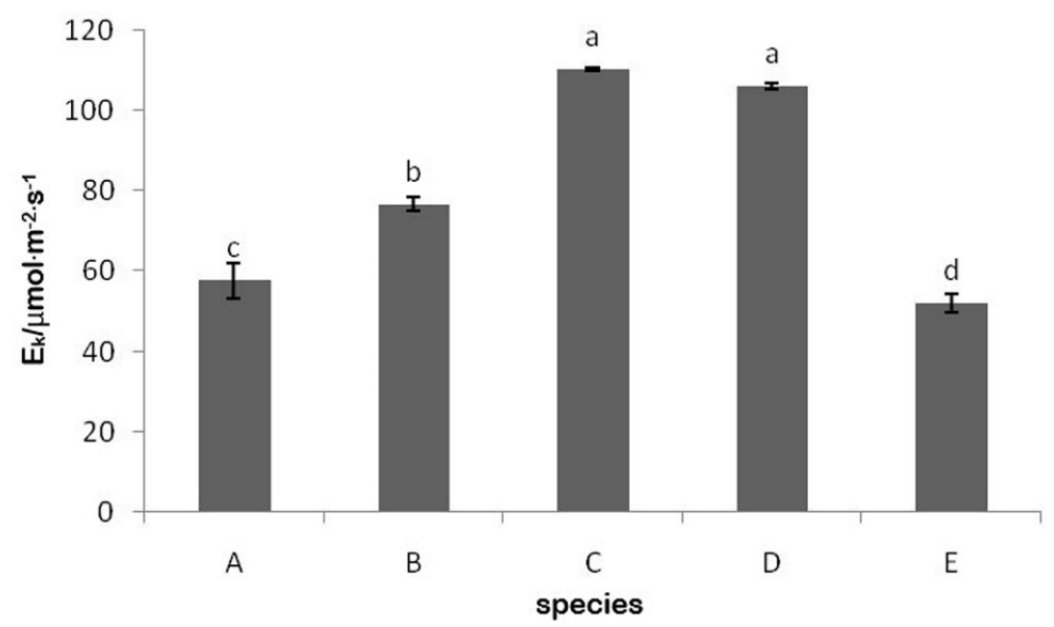

Figure 5. Comparative study on the $\mathrm{E}_{\mathrm{k}}$ of five submerged macrophytes

\section{Discussion}

Submerged plants have the ability to self-regulate and adapt to the environment, they can adjust the distribution of resources in the plant body for adapting to the environment, which is often manifested as changes in the growth and physiological parameters (Li et al., 2008). Photosynthetic fluorescence parameters in leaves closely relate to photosynthesis in plants and accurately reflect the actual situation of plant photosynthesis in certain circumstances (Guo and Tan, 2015).

$F_{v} / F_{m}$, the maximum quantum yield of PSII, reflects the potential light energy conversion efficiency of the PSII reaction center, and this efficiency is independent of species (Cao et al., 2012; Cheng et al., 2014). $F_{v} / F_{m}$ changes little under non-stress conditions and measures approximately 0.83 in most higher plants; the value is significantly reduced in plants subjected to environmental stress. In the present study, $F_{v} / F_{m}$ of 5 plants are less than 0.8 , showing that the 5 kinds of submerged plants may be intimidated, meanwhile, outside stress may do some damage to the PSII reaction center of submerged plants (Jian et al., 2016). While the variation trends of $F_{v} / F_{m^{\prime}}$ and $\mathrm{F}_{\mathrm{v}} / \mathrm{F}_{\mathrm{m}}$ were same. At present, there have been reports on the effects of UV-B radiation, polycyclic aromatic hydrocarbon pollution and the attachment of reticulosa on $F_{v} / F_{m}$ of aquatic plants (Marwood et al., 2001; Li et al., 2009) and the effects of other factors on $F_{v} / F_{m}$ is seldom reported. Combined with the water quality in the sampling area, the most likely reason for the decrease of $F_{v} / F_{m}$ value of submerged plants in the sampling area is the attached filamentous algae (Song et al., 2009). As for the tolerance of $F_{v} / F_{m}$ of different plants to stress factors, further studies are needed.

$\alpha$, which reflects the level of the light-harvesting capacity of leaves, is associated with the light absorption coefficient of leaves and the light utilization efficiency of PSII. In this study, different species have different $\alpha$ values, $P$. crispus $\mathrm{L}$. and $M$. verticillatum $\mathrm{L}$. are relatively high in the five species. While the variation trends of $\mathrm{rETR}_{\mathrm{m}}$ and $\mathrm{E}_{\mathrm{k}}$ were basically the same. P. crispus $\mathrm{L}$. and $M$. verticillatum $\mathrm{L}$., both of which have high photosynthetic efficiency, have excellent ability to withstand hard light. $\alpha$ of $V$. natans (Lour.) Hara is the lowest, it suggests that $V$. natans (Lour.) Hara has a strong ability to withstand weak light.

Previous report showed that with only $5 \%$ natural light intensity, V. natans (Lour.) Hara cell membrane permeability still had no obvious change, so it had a strong growth advantage in the bottom of natural water, which may be a pioneer species in the restoration of eutrophic water (Xiao et al., 2006). 


\section{Conclusions}

Different species have different characteristics of light and fluorescence. External stress may affect $F_{V} / F_{m}$ of five submerged plants in Honghu Lake. The photosynthetic capacity of submerged plants is greatly affected by the light response curve, different species have different tolerances to light intensity. Among the five species, $V$. natans (Lour.) Hara has the strongest tolerance to low light and can be used as a pioneer in eutrophication restoration in shallow lakes. In summary, in the ecological restoration of shallow lakes $150 \mathrm{~cm}$ deep in the middle and lower reaches of the Yangtze River, the arrangement sequence of five submerged plants is $V$. natans (Lour.) Hara, $P$. wrightii Morong, $H$. verticillata, $M$. verticillatum L. and P. crispus L. from deep to shallow. In this study, the photosynthetic fluorescence characteristics of five submerged plants at $150 \mathrm{~cm}$ water depth were measured and analyzed, the comparison of photosynthetic fluorescence characteristics of various submerged plants under different water depth gradients in natural water need to be further studied.

\section{Authors' Contributions}

Conceptualization: YQZ,BHJ and LYY; Data curation: YQZ and BHJ; Form analysis: BHJ and LYY; Funding investigation acquisition: YQZ and BHJ; Methodology: YQZ and BHJ; Project administration: LYY; Resources: LYY; Software: YQZ; Supervision: YQZ; Validation; YQZ; Visualization: YQZ and BHJ; Writing-original draft: YQZ and BHJ; Writing-review and editing: YQZ, BHJ and LYY. All authors read and approved the final manuscript.

\section{Acknowledgements}

This work was supported by National Nature Foundation Projects (China), grant number 31170400 and 31460132 .

\section{Conflict of Interests}

The authors declare that there are no conflicts of interest related to this article.

\section{References}

Bal DB, Sungjin K, Kwangsoon C, Woomyung H (2017). Assessment of long-term physicochemical water quality variations by PCA technique in Lake Hwajinpo, South Korea. Journal of Environmental Protection 8(13):16361651. https://doi.org/10.4236/jep.2017.813101

Barko JW, Smart RM (1981). Comparative influences of light and temperature on the growth and metabolism of selected submersed freshwater macrophytes. Ecological Monographs 51(2):219-236. https://doi.org/10.2307/2937264

Belshe EF, Durako MJ, Blum JE (2007). Photosynthetic rapid light curves (RLC) of Thalassia testudinum exhibit diurnal variation. Journal of Experimental Marine Biology and Ecology 342(2):253-268. https://doi.org/10.1016/j.jembe.2006.10.056

Bornette G, Puijalon S (2011). Response of aquatic plants to abiotic factors: a review. Aquatic Sciences 73(1):1-14. https://doi.org/10.1007/s00027-010-0162-7

Cao YH, Zhou BZ, Zhang RM, Chen SL (2012). Response of chlorophyll fluorescence parameters of Illicium lanceolatum on different light conditions. Acta Botanica Boreali-Occidentalia Sinica 32(3):525-531. 
Cheng XR, Shu J, Liu J, Wang W, Yu MK. (2014). Photosynthesis and fluorescence characteristics of Begonia fimbristipula and Gynura divaricata under different light conditions. Acta Botanica Boreali-Occidentalia Sinica34(7):1426-1431. https://doi.org/10.7606/j.issn.1000-4025.2014.07.1426

David WS, Hecky RE, Findlay DL, Stainton MP, Parker BR, Paterson MJ, ... Kasian SEM (2008). Eutrophication of lakes cannot be controlled by reducing nitrogen input: results of a 37-year whole-ecosystem experiment. Proceedings of the National Academy of Sciences of the United States of America 105(32):11254-11258.

Gudrun B, Sara P (2011). Response of aquatic plants to abiotic factors: a review. Aquatic Sciences 73(1):1-14. https://doi.org/10.1007/s00027-010-0162-7

Guo Y, Tan J (2015). Recent advances in the application of chlorophyll a fluorescence from photosystem II. Photochemistry Photobiology 91(1):1-14. https://doi.org/10.1111/php.12362

Hallik L, Niinemets U, Kull O (2012). Photosynthetic acclimation to light in woody and herbaceous species: a comparison of leaf structure, pigment content and chlorophyll fluorescence characteristics measured in the field. Plant Biology 14(1):88-99. https://doi.org/10.1111/j.1438-8677.2011.00472.x

Hussain T, Huchzenmeyer B, Koyro HW, Khan MA (2019). Linkage between leaf development and photosynthetic response at hyperosmotic salinity in the C-4 grass Panicum antidotale. Flora 256:52-60. https://doi.org/10.1016/j.flora.2019.05.003

Jian MF, Wang SC, Yu HP, Li LY, Yu GJ (2016). Effects of $\mathrm{Cd} \sim(2+)$ and $\mathrm{Cu}(2+)$ stress on the growth and photosynthetic fluorescence of Hydrilla verticillata. Acta Ecologica Sinica 36(06):1719-1727.

Küster A, Altenburger R (2007). Development and validation of a new fluorescence-based bioassay for aquatic macrophyte species. Chemosphere 67(1):194-201. https://doi.org/10.1016/j.chemosphere.2006.08.023

Lamote M, Dunton KH (2006). Effects of drift macroalgae and light attenuation on chlorophyll fluorescence and sediment sulfides in the sea grass Thalassia testudinum. Journal of Experimental Marine Biology and Ecology 334(2):174-186. https://doi.org/10.1016/j.jembe.2006.01.024

Liao M, Yu G, Guo Y (2017). Eutrophication in Poyang Lake (Eastern China) over the last 300 years in response to changes in climate and lake biomass. PloS One 12(1):e0169319. https://doi.org/10.1371/journal.pone.0169319

Li HJ, Ni LY, Cao T, Zhu LX (2008). Responses of Vallisneria natans to reduced light availability and nutrient enrichment. Acta Hydrobiologica Sinica 32(2):225-230.

Li Q, Wang GX, Ma T, Wang WL, Pan GQ (2007). Changes of photosynthetic characters of Vallisneria asiatica adhered by Hydrodictyon reticulatunm. Journal of Lake Sciences 19(3):315-320.

Li W (1997). Flora studies on aquatic vascular plants in Honghu Lake. Journal of Wuhan Botanical Research 15(2):113122.

Liu SR, Guo SR, Cheng YJ, Liu CJ, Wang LP, Shu S (2010). Effect of exogenous proline on the ascorbat-glutahione cycle and photosynthetic fluorescence characteristics in leaves of cucumber seedlings under high temperature Stress. Acta Botanica Boreali-Occidentalia Sinica 30(2):309-316.

Liu J, Hu XT, Wang WE, Ran H, Fang ST, Yang X (2019). Effects of light intensity and photoperiod on photosynthesis and chlorophyll fluorescence of hydroponic lettuce. Southwest China Journal of Agricultural Science 32(08):1784-1790. https://doi.org/10.16213/j.cnki.scjas.2019.8.016

Lu S, Li SJ, Wang XL (2004). Study on the environmental evolution and ecological protection of Honghu Lake. Wetland Science 2(3):234-237. https://doi.org/10.13248/j.cnki.wetlandsci.2004.03.012

Marwood CA, Solomon KR, Greenberg BM (2001). Chlorophyll fluorescence as a bioindicator of effects on growth in aquatic macrophytes from mixtures of polycyclic aromatic hydrocarbons. Environmental Toxicology and Chemistry 20(4):890-898. https://doi.org/10.1002/etc.5620200425

Platt T, Gallegos CL, Harrison WG (1980). Photoinhibition of photosynthesis in natural assemblages of marine phytoplankton. Journal of Marine Research 38:103-111.

Qin BQ, Gao G, Zhu GW, Zhang YL, Song YZ, Tang XM, ... Deng JM (2013). Lake eutrophication and its ecosystem response. Science Bulletin 58(09):961-970.

Ralph PJ, Gademann R (2005). Rapid light curves: a powerful tool to assess photosynthetic activity. Aquatic Botany 82(3):222-237. https://doi.org/10.1016/j.aquabot.2005.02.006

Ralph PJ, Gademann R, Dennison WC (1998). In situ seagrass photosynthesis measured using a submersible, pulseamplitude modulated fluorometer. Marine Biology 132(3):367-373. https://doi.org/10.1007/s002270050403

Smith VH, Schindler DW (2009). Eutrophication science: where do we go from here? Trends in Ecology \& Evolution 24(4):201-207. https://doi.org/10.1016/j.tree.2008.11.009 
Song YZ, Cai W, Qin BQ (2009). Photosynthetic fluorescence characteristics of floating-leaved and submersed macrophytes commonly found in Taihu Lake. Chinese Journal of Applied Ecology 20(3):569-573.

Waldhoff D, Furch B, Junk WJ (2002). Fluorescence parameter, chlorophyll concentration, and anatomical features as indicators for flood adaptation of an abundant tree species in central Amazonia: Symmeria paniculata. Environmental and Experimental Botany 48(3):225-235. https://doi.org/10.1016/S0098-8472(02)00037-0

Wang CB, Wang H, Zhao XM, Chen BH, Wang FL (2015). Mulching affects photosynthetic and chlorophyll a fluorescence characteristic during stage III of peach fruit growth on the rain-fed semiarid Loess Plateau of China. Scientia Horticulturae 194:246-254. https://doi.org/10.1016/j.scienta.2015.08.012

Wang HJ, Wang HZ (2009). Mitigation of lake eutrophication: Loosen nitrogen control and focus on phosphorus abatement. Progress in Natural Science 19(10):1445-1451. https://doi.org/10.1016/j.pnsc.2009.03.009

Wu ZY (2007). Flora of China. Science Press (4th ed), Beijing.

Xiao YE, Chen KN, Dai XB, Chen XF, Xu XM (2006). Comparison of adaptive capacity to low light intensity of two angiosperm submerged macrophytes from Taihu lake. Plant Physiology Communication 42(3):421-425.

Xie PJ, Li MH, Yan LR, Qiao YL (2016). Effects of three submerged plants on Cu and Pb contaminated sediment. Journal of Agro-Environment Science 35(04):757-763.

Yang J, Wang Z, Li EH, Song XX, Wang XL (2015). Physiological characteristics of Hydrilla verticillata and Ceratophyllum demersum under different sediment conditions in Dianchi Lake. Wetland Science 13(04):430436. https://doi.org/10.13248/j.cnki.wetlandsci.2015.04.007

Yang LK, Peng S, Zhao XH, Li X (2017). Development of a two-dimensional eutrophication model in an urban lake (China) and the application of uncertainty analysis. Ecological Modelling 345:63-74. https://doi.org/10.1016/j.ecolmodel.2016.11.014

Zhang SR (1999). A discussion on chlorophyll fluorescence kinetics parameters and their significance. Chinese Bulletin of Botany 16(4):444-448.

Zhang M, Li XQ, Li ZQ, Liu ZG, Lu L (2015). Comparative experimental study on nitrogen and phosphorus purification from eutrophic water by two submerged plants with multi-lobed leaves. Resources and Environment in the Yangtze Basin 24(S1):182-190. https://doi.org/10.11870/cjlyzyyhj2015Z1024

Zhang YJ, Liu XP, Jin J, Dong Y, Duan T, Zhang MM, ... Zhen L (2012). Research progress in submerged plant purifying water quality. Science \& Technology Review 30(27):72-79. https://doi.org/doi10.3981/j.issn.10007857.2012.27.012

Zhao FB, Wei Z, Liu YH, Wang LQ (2018). Responses of growth and photosynthetic fluorescent characteristics in Ottelia acuminata to a water-depth gradient. Journal of Freshwater Ecology 33(1):285-297. https://doi.org/10.1080/02705060.2018.1443841

Zhong J, Zhang H, Xiong XY (2018). Leaf structure and photosynthetic fluorescence characteristics of Houttuynia cordata Thunb seedlings respond to different light quality. Journal of Hunan Agricultural University (Nat Sci), China 44(06):592-596. https://doi.org/10.13331/j.cnki.jhau.2018.06.004
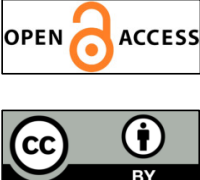

The journal offers free, immediate, and unrestricted access to peer-reviewed research and scholarly work. Users are allowed to read, download, copy, distribute, print, search, or link to the full texts of the articles, or use them for any other lawful purpose, without asking prior permission from the publisher or the author.

License - Articles published in Notulae Botanicae Horti Agrobotanici Cluj-Napoca are Open-Access, distributed under the terms and conditions of the Creative Commons Attribution (CC BY 4.0) License. (c) Articles by the authors; UASVM, Cluj-Napoca, Romania. The journal allows the author(s) to hold the copyright/to retain publishing rights without restriction. 